\title{
Asymptomatic internal hernia through a defect of broad ligament: a surprising finding in a laparoscopic surgery to recover a lost levonorgestrel- releasing intrauterine system
}

\author{
Fedra Rodrigues, ${ }^{1}$ Inês Sarmento, ${ }^{2}$ Pedro Tiago ${ }^{2}$
}

${ }^{1}$ Hospital de Braga, Braga, Portugal

${ }^{2}$ Hospital Pedro Hispano, Matosinhos, Portugal

\section{Correspondence to}

Dr Fedra Rodrigues,

rodrigues.fedra@gmail.com

Accepted 15 December 2014

CrossMark

To cite: Rodrigues $F_{\text {, }}$

Sarmento I, Tiago P. BMJ

Case Rep Published online:

[please include Day Month

Year] doi:10.1136/bcr-2014-

206804

\section{DESCRIPTION}

We present a case of a 47-year-old nulliparous woman, with no relevant medical or surgical history, who underwent insertion of a levonorgestrelreleasing intrauterine system (LNG-IUS) during benign vulvar surgery with general anaesthetic.

Four weeks later, during a routine ultrasound examination to confirm the correct placement of the IUS, the device was shown to be missing. CT scan

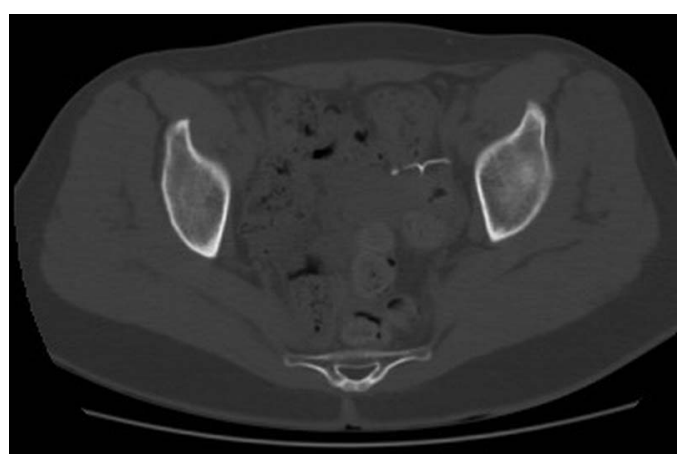

Figure 1 CT scan showing the levonorgestrel-releasing intrauterine system. revealed the LNG-IUS to be in the right adnexal region (figure 1). Laparoscopic surgery was planned to remove it.On the day of surgery, an abdominal X-ray revealed different LNG-IUS localisation depending on patient positioning (figure 2).

Laparoscopic exploration, guided by information from the abdominal X-ray in the supine position, revealed the LNG-IUS in mid-upper abdomen, embedded in omentum tissue; it was removed easily. During the procedure, the small bowel was seen to be herniated $(7 \mathrm{~cm}$ ileum's length) through a defect in the right broad ligament and adherent to the pouch of Douglas by fine adhesions, making exploration of the pelvis difficult. The small bowel hernia was reduced from the defect back to the abdominal cavity (figure 3) and there was no evidence of vascular compromise. The defect of the broad ligament was also present on the left (figure 4). The surgery was uneventful and the patient was discharged the next day.

The preoperative diagnosis of an internal hernia through the broad ligament was not possible because there was no clinical suspicion (absence of symptoms or signs) or evidence in the performed examinations.

Figure 2 Abdominal X-ray showing the levonorgestrel-releasing intrauterine system (arrowed) in (A) orthostatic position and (B) supine position.
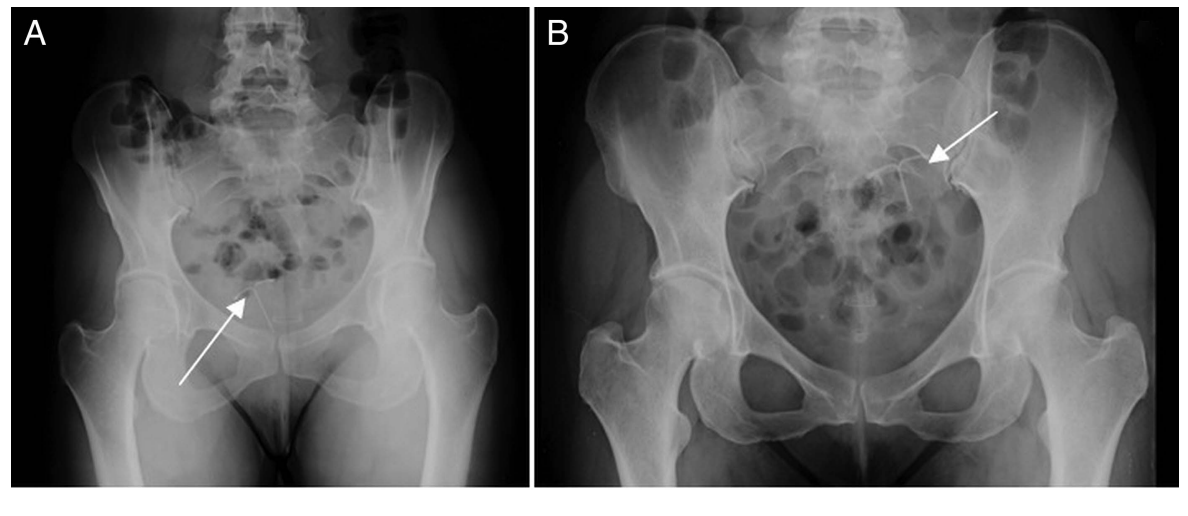


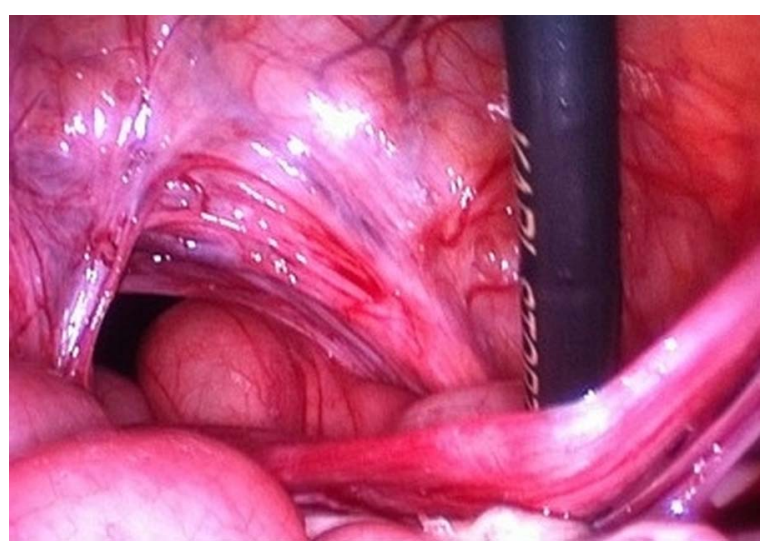

Figure 3 Herniation of small bowel through a defect in the right broad ligament.

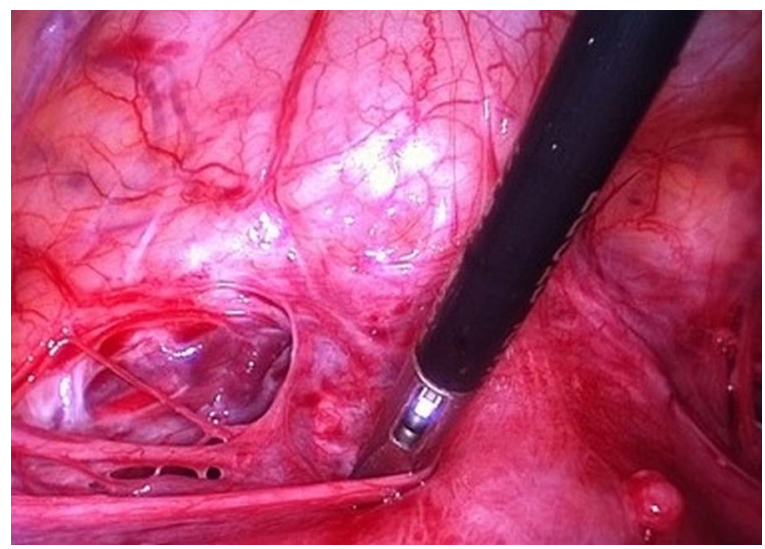

Figure 4 Defect in the left broad ligament.

\section{Learning points}

- Uterine perforation occurs in less than 1 in 1000 intrauterine levonorgestrel-releasing intrauterine system (LNG-IUS) insertions. ${ }^{1}$ The lost LNG-IUS is more frequently found in the mid-upper abdomen, so this area should be the first place explored during laparoscopy. ${ }^{2}$ It is helpful to perform an abdominal X-ray in supine position on the day of surgery.

- Internal hernias represent less than $1 \%$ of all hernias. Herniation of small bowel through a defect of the broad ligament is an extremely rare event, accounting for $4-7 \%$ of all internal hernias. ${ }^{3}$

- The precise pathogenesis of a defect of the broad ligament remains unknown; it can be either congenital (ruptured cystic structures reminiscent of the mesonephric ducts) or secondary to surgery, pregnancy and birth trauma or prior pelvic inflammatory disease. In this case, a congenital cause is plausible because of bilateral defects and absence of relevant clinical or surgical history.

Contributors All authors contributed in writing and correcting the article.

Competing interests None.

Patient consent Obtained.

Provenance and peer review Not commissioned; externally peer reviewed.

\section{REFERENCES}

1 Faculty of Family Planning and Reproductive Health Care Guidance. FFPRHC Guidance (April 2004). The levonorgestrel releasing intrauterine system (LNG-IUS) in contraception and reproductive health. J Fam Plann Reprod Health Care 2004;30:99-108.

2 Nitke S, Rabinerson D, Dekel A, et al. Lost levonorgestrel IUD: diagnosis and therapy. Contraception 2004;9:289-93.

3 Hiraiwa $\mathrm{K}$, Morozumi K, Miyazaki $\mathrm{H}$, et al. Strangulated hernia through a defect of the broad ligament and mobile cecum: a case report. World I Gastroenterol 2006;12:1479-80.

Copyright 2015 BMJ Publishing Group. All rights reserved. For permission to reuse any of this content visit http://group.bmj.com/group/rights-licensing/permissions.

BMJ Case Report Fellows may re-use this article for personal use and teaching without any further permission.

Become a Fellow of BMJ Case Reports today and you can:

- Submit as many cases as you like

- Enjoy fast sympathetic peer review and rapid publication of accepted articles

- Access all the published articles

- Re-use any of the published material for personal use and teaching without further permission

For information on Institutional Fellowships contact consortiasales@bmjgroup.com

Visit casereports.bmj.com for more articles like this and to become a Fellow 